\title{
Edomophobia?: An exilic or a post-exilic reading of Doeg in 1 Samuel 21 and 22
}

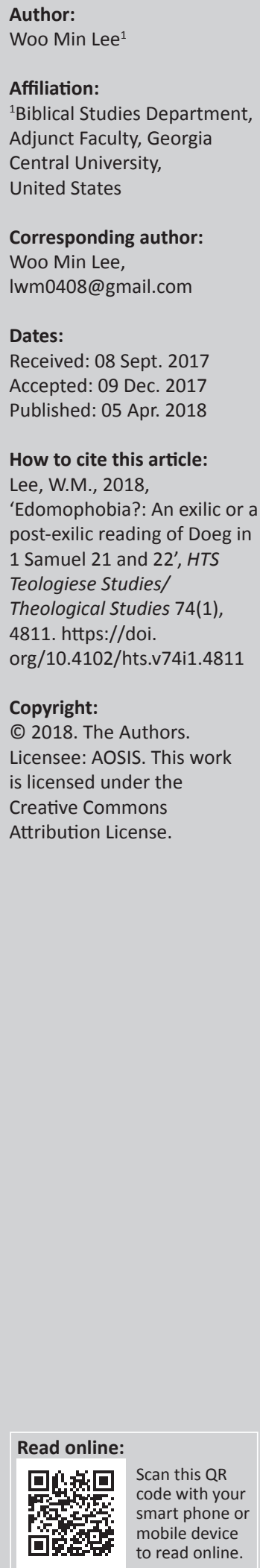

There have been historical and literary studies on the pre-deuteronomistic narrative of 1 Samuel 21 and 22. However, there have been few studies on the reception of Doeg the Edomite among the exilic and post-exilic communities. This article tries to show how the minor character of Doeg the Edomite in 1 Samuel 21 and 22 was understood by the exilic and postexilic communities after the fall of Jerusalem. With this objective in mind, the article analyses the literary structure of 1 Samuel 21 and 22 with a focus on Doeg. Along with the literary approach to the text, it examines the historical setting of the exilic and post-exilic communities regarding their cultural memory and enmity towards Edomites. The conflict between Edom and Israel has been constantly described in the biblical text including the Deuteronomistic History. The enmity of Israel towards Edom had been worse after the fall of Jerusalem. The pre-deuteronomistic record of Doeg in 1 Samuel 21 and 22 would have been used as a propagandistic device to reinforce the enmity of the exilic and post-exilic communities towards Edom and Edomites.

\section{Introduction}

Doeg the Edomite plays an important role in the conflict between Saul and Ahimelech and its aftermath in 1 Samuel 21 and 22. As a part of 'History of David's Rise', the narrative begins with David's visit to Ahimelech, a priest in Nob, and ends with Doeg's slaughter of the people and the animals of the city, followed by the fleeing of Abiathar to David. Compared to Saul and David, Doeg is a minor character who was introduced as one of King Saul's servants (1 Sam 21:8 BHS/1 Sam 21:7 NRSV) but plays an important role in the narrative. He brought about a conflict or confrontation between Saul and Ahimelech and resolved it in a violent way at the conclusion of the narrative. His name is written with his ethnicity three times throughout the narrative of 1 Samuel 21 and $22 .^{1}$

A possible question about Doeg in the narrative would be an exilic or a postexilic understanding of this Edomite character. The narrative of 1 Samuel 21 and 22 has been considered as a pre-deuteronomistic record included in the Deuteronomistic History (DH). In other words, the narrative itself is a pre-deuteronomistic document, but the exilic or postexilic readers or audience would read it in their own historical setting. Firstly, this article analyses the literary structure of 1 Samuel 21 and 22 with a focus on Doeg. Along with its literary structure, it reconstructs the exilic or post-exilic understanding of Edom after the fall of Jerusalem. Based on this twofold analysis, the article argues that the character of Doeg the Edomite reinforced 'Edomophobia' of the audience or readers in their exilic or post-exilic context.

\section{Textual analysis in 1 Samuel 21 and 22}

In 1 Samuel 21, David visited Nob and met Ahimelech. He asked the priest for five loaves of bread (1 Sam 21:4 BHS/1 Sam 21:3 NRSV). After his request for the bread, there is an interruption by a seemingly untimely introduction of Doeg, one of the servants of Saul (1 Sam 21:8 BHS/1 Sam 21:7 NRSV), who was 'detained before the LORD (נעצר לפני יהוה) at the temple in Nob (1 Sam 21:8 BHS/1 Sam 21:7 NRSV)'. ${ }^{2}$ This clause has not yet been clearly explained. It is not clear whether it was for a religious reason or any other reason (Lozovyy 2009:90-95; Sasson 2004:318-319). At least, it is clear that Doeg the Edomite was present at the temple when David visited Ahimelech (Alter 1999:132). His presence at the temple in Nob can even be considered as a portent for any upcoming event in the narrative (Brueggemann 1990:155; Hertzberg 1964:180; Klein 1983:213).

1.1 Samuel $21: 7 ; 22: 9 ; 22: 18$ (note that his name is written without his ethnicity two times in $22: 18$ ).

2.Robert Alter suggests that the intrusive notation of Doeg is a piece of ominous foreshadowing (Alter 1981:66). 
Then, the story comes back to David and Ahimelech, with David's request for a weapon (1 Sam 21:9 BHS/1 Sam 21:8 NRSV).

In the later part of 1 Samuel 21 and in the beginning section of 1 Samuel 22, David continued his wandering to Gath (1 Sam 21:11-16 BHS/1 Sam 21:10-15 NRSV), the cave of Adullam (1 Sam 22:1-2 BHS/NRSV), Moab (1 Sam 22:3-5a BHS/NRSV) and, finally, Hereth (1 Sam 22:5b BHS/NRSV).

The scene of the narrative suddenly changes from the wandering of David to the anger of Saul towards David (1 Sam 22:6-8 BHS/NRSV). Saul heard that David and those who were with him had been located. ${ }^{3}$ He asked his servants, who stood around him, what kind of benefits David would provide them. His remarks are expressed in question forms but they are not questions. They actually convey Saul's negative and even hostile statement about David.

At the moment, Doeg the Edomite ${ }^{4}$ appeared once again in the narrative (1 Sam 22:9). In Saul's questions, he reported that he had witnessed David's visit to Ahimelech in Nob (1 Sam 22:9-10). In his report, he described that the priest petitioned God for David and even provided provision and the sword of Goliath. An interesting point about his report is that he described the priest's inquiry of God for David, which was not described in 1 Samuel 21, meaning 'provision (1 Sam 22:10)' instead of לחם, meaning 'bread (1 Sam 21:4,5, and 7 BHS/1 Sam 21:3,4, and 6 NRSV)'.

Doeg's report about David and Ahimelech is followed by an intense face-to-face confrontation between Saul and Ahimelech. The Edomite servant of Saul stirred up his master against David (Jobling 1998:285). Saul sent for Ahimelech and all of the priests who were at Nob. When they came to the king, Saul asked, למה קשרתם עלי, meaning, 'why did you conspire against me? (1 Sam 22:13a)'. His question or interrogation continued. In particular, he asked Ahimelech regarding his inquiry of God for David, לחם, the 'bread', and, חרב, the 'sword' (1 Sam 22:13b).

With the critical questions from Saul, Ahimelech refuted the king's blame. He did not deny what he had done for David. Instead, he claimed that David was Saul's faithful servant (1 Sam 22:14). He also asked the king not to impute anything to David or any member of the house of Ahimelech's father (1 Sam 22:15).

After the priest's answer, Saul claimed that all of the priests, including Ahimelech, should die (1 Sam 22:16). When he commanded his guards to turn and kill them, they hesitated to kill the priests of the LORD (1 Sam 22:17). They placed

3.Keith Bodner suggests that Saul had 'eyes and ears' throughout the land (Bodner 2008:233).

4.Doeg is described as 'the Edomite' (האדמי) in MT and LXX' while he is depicted as 'the

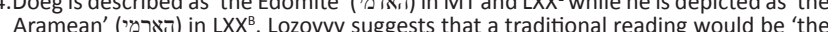
Edomite' (Lozovyy 2009:86).

5.Bodner suggests that Doeg added the inquiry to his report in order to rile Saul and further indict the priest (Bodner 2008:235). their fear of the LORD above their fear of the king (Tsumura 2007:546). The tension between Saul and the priests was not being resolved because of his servants' hesitation. Furthermore, another tension between the king and his guards was raised at that moment.

In the critical moment, Saul pointed out Doeg and ordered him to turn and attack the priests (1 Sam 22:18a). At his command, this Edomite servant of Saul killed 85 priests, including Ahimelech. His actions did not end with the priests. He also killed men and women, children and infants, oxen, donkeys and sheep in the city of Nob (1 Sam 22:19). Aster suggests that his title, אביר הרעים, is related to his military role (Aster 2003:361). Based upon this suggestion, Doeg killed the priests of the LORD as a military officer of Saul. Sasson suggests that his title is related to his role as a liaison for intelligence reasons (Sasson 2004:319-321). He also highlights his status as a foreigner who was a loyal servant of Saul (Sasson 2004:321-322). With his military role and foreign status, the narrators could associate the killing of the priests of Nob with Doeg without having any Israelite servant of Saul involved in the incident (Sasson 2004:322). Doeg can also be considered as a deus ex machina in that his deed fulfilled a prophecy on Eli's descendants (1 Sam 2:33) except for Abiathar, who was later dismissed by Solomon (1 Ki 2:2627) (Fokkelman 1986:409-410; Sasson 2004:322).

The narrative changes its focus again from Saul to David. Abiathar, who was one of the sons of Ahimelech, escaped and fled to David (1 Sam 22:20). When Abiathar reported that Saul killed the priests of the LORD (1 Sam 22:21), David said that he saw Doeg at the temple in Nob, and expected that Doeg would tell Saul (1 Sam 22:22). The narrative concludes with David's request to Abiathar to stay with him (1 Sam 22:23).

\section{Edom and Edomites in the Deuteronomistic History}

After a story of the struggle between Esau and Jacob in the womb of Rebekah in Genesis 25:19-34 and the list of Esau's descendants in Genesis 36, the conflict between Israel and Edom can be found several times in the DH. Saul fought against his enemies, including the Edomites (1 Sam 14:47), but he also had an Edomite servant, Doeg (1 Sam 21-22). ${ }^{6}$ Later, David employed campaigns against Edom and defeated the kingdom (2 Sam 8:13-14; 1 Ki 11:15-16). Hadad the Edomite was described as one of the adversaries against Solomon (1 Ki 11:14-22). Little evidence about Edom during the reign of Solomon and his immediate successors has been found (Bartlett 1992:290). There was no king in Edom and a deputy was king during the reign of Jehoshaphat

6.As a servant of Saul against David, Doeg is mentioned in a few biblical texts. Other than in 1 Samuel 21-22, Doeg appears in Psalm 52, which seems to reflect a conflict than in 1 Samuel 21-22, Dog appears in Psal 52 , which during the post-exilic temple period (Tate 1990:36). Compared to 1 Samuel, 1 Chronicles briefly describes the death of Saul and his sons (1 Chr 10) without any further information including Doeg. Kalimi suggests that the books of Chronicle focus on the history of Davidic dynasty with a particular attention to the temple and its services (Kalimi 1997:88). Therefore, it is possible that the narrative of Doeg would not be included in Chronicles. 
(1 Ki 22:47-48). Jehoram, Jehoshaphat and the king of Edom employed a campaign against the kingdom of Moab $(2 \mathrm{Ki}$ 3:4-27). Later, Edom set up a monarchy during the reign of Joram (2 Ki 8:20-22) and remained as an independent kingdom until its submission to Assyria (Bartlett 1992:290).

There have been consistent disputes about a possible writing date of the 'History of David's Rise', including the episode of Doeg (Klein 1983:xxviii-xxxiii; McCarter 1980:12-30; Römer 2007:91-97). The account of the Edomite servant of Saul in 1 Samuel 21-22 mainly describes a heightened tension between Saul and David followed by the slaughter of the priests of the LORD (Peterson 2014:228-229). The narrative is not explicitly connected to the deuteronomistic ideology of fidelity to the LORD or to the cultic centralisation in Jerusalem (Campbell \& O'Brien 2000:219, 268-270). Therefore, this account might fit better in the pre-deuteronomistic record.

\section{Judah and Edom after the fall of Jerusalem}

One of the critical issues regarding the relationship between Edom and the kingdom of Judah in the biblical text was the fall of Jerusalem under the Babylonian Empire in 587 BCE. Any detailed evidence about the kingdom of Edom under the rule of the empire is rarely found in the Babylonian resources or in biblical texts. Instead, some biblical texts mention Edom in relation to the fall of Jerusalem by Nebuchadnezzar II. Those texts assume that Edom assisted the Babylonians in the sacking of Jerusalem (Lm 4:21-22; Is 34; Ml 1:2-5; J1 3:19 [4:19 BHS]; Ezk 25:12; 35:3, 15; Ps 137:7; Ob 11), but there is no clear evidence to support Edom's assistance in the destruction of Jerusalem by the empire. Bartlett suggests that those texts are largely based on the imaginative communal memory of Edom's traditional enmity rather than on the precise knowledge of Edom's activity in 587 BCE (Bartlett 1989:151157; 1992:292). However, it is possible that Edom might have become a vassal of the Babylonian Empire with Judah and other states under the rule of Nebuchadnezzar after 605 BCE (Bartlett 1992:292). He also suggests that the most reliable source is Jeremiah 40:11, which describes that there were Judaean refugees in Edom (Bartlett 1992:292).

Furthermore, Tebes suggests that the general enmity of the biblical text towards Edom was a political ideology resulting from the xenophobia of the Golah community after the fall of Jerusalem (Tebes 2011:255). According to him, the 'stab-in-theback' tradition naturally evolved among circles of the Judaean elites who did not tolerate the predominant Edomite presence in lands of the erstwhile Judaean monarchy and the elites who resisted the claims of the Edomite people or their supporters to cultic offices in the temple of Jerusalem (Tebes 2011:255). He agrees with Bartlett that the tradition of the Edomite participation in the sack of Jerusalem was not so much based on the historical events of the fall of Jerusalem, but rather on how the Judaeans perceived the behaviour of the Edomites (Tebes 2011:232). This fictional enmity towards the Edomites resembles the so-called 'stab-in-the-back' traditions present in modern defeated nations (Tebes 2011:232).
Tebes suggests that a possible reason why the exilic and post-exilic communities blamed the Edomites would be their presence in the late Judaean kingdom based on archaeological excavations (Tebes 2011:241). Another possible reason would be the presence of the Edomites or the Edomite cultic practices in ancient Israel (2 Chr 25:14) (Tebes 2011:244). It is quite possible that the presence of the Edomites in Judah and their cultic practices might have caused the Golah community to express their xenophobia and create the myth of the 'stab-in-the-back' tradition against the Edomites (Tebes 2011:250).

On the contrary, Lemaire suggests that the recurrent biblical condemnations of Edom would provide the historical value about the involvement of Edom in the sacking of Jerusalem in 587 BCE (Lemaire 2010:239-240). According to him, Edom helped the Babylonian Empire in the military campaign against Jerusalem and took the South of the Judaean kingdom as a reward from the empire (Lemaire 2010:239-240).

However, Lemaire's argument seems to be weak when compared to the arguments of Bartlett and Tebes. If Edom had been involved in the sacking of Jerusalem as Lemaire argues, the post-exilic documents could have clearly described it to blame the kingdom of Edom after its fall in 552 BCE (Lemaire 2006:290). None of the exilic and postexilic documents provides any detail about the role of Edom in the fall of Jerusalem. The Babylonian record simply describes the conquest of Jerusalem without any further details (Pritchard 1969:564). In the consistent disputes, it seems to be clear that Edom maintained a politically favourable attitude towards Babylonian Empire in the revolt of Judah, Ammon and Moab against the empire (Lemaire 2010:239), even though Edom did not play any active role in the destruction of Jerusalem.

\section{Conclusion}

The pre-deuteronomistic narrative of Doeg can be considered as playing a double role to the readers in the exilic or post-exilic situations. In the literary setting, the Edomite servant embodies Saul's defectiveness in terms of personality and kingship. In his confrontation with Ahimelech, he ordered his servants to kill Ahimelech and other priests of the LORD. Being informed and even stirred up by his Edomite servant, Saul revealed his imprudent and violent character in his conflict with David. His servants hesitated to obey his command, but he did not pull back. Instead, he gave the same order to Doeg. The Edomite servant slaughtered the whole population and the animals of Nob, which was beyond Saul's order. Lozovyy describes Doeg as the embodiment of the evil spirit that YHWH sent to Saul (Lozovyy 2009:152). More than the evil spirit's embodiment, Doeg can be considered as the embodiment of Saul's violence. Saul's personal defectiveness resulted in the mass slaughter of the whole city of Nob with the aid of his Edomite servant.

Along with Saul's problematic personality, the narrative reveals Saul's defective kingship, which (re)confirms the 
validity of David's kingship given from the LORD. As mentioned above, Saul himself did not kill the priests of the LORD including Ahimelech, but gave an order to his servants to slaughter them. His servants' hesitance to follow his order cast a doubt about the reasonability of the order as the anointed king of the LORD. It seems that he was lacking sense in making an appropriate decision. His servants' reluctance also can be marked as a crack in the authority of Saul's kingship over his people. Meanwhile, Doeg did not hesitate to step up. His ethnicity was written again and it was related to his extremely violent and even blasphemous action against the LORD. As Saul was the commander who made the order, the massacre of the city in the hands of Doeg alludes to the negation of Saul's kingship, which leads to the justification of David's kingship. This narrative reveals the downward slope of Saul's kingship. Römer suggests that the fate of Saul alludes to the collapse of the Northern kingdom in 722 BCE (Römer 2007:93).

When included in the $\mathrm{DH}$ later, this pre-deuteronomistic narrative of Doeg took the second role to reinforce the exilic or post-exilic community's xenophobia against the Edomites or 'Edomophobia'. The conflict between Edom and Israel has been consistently described in biblical texts. In particular, there has been an assumption about the role of Edom in the fall of Jerusalem. The account of Doeg is also in the line of the deep-rooted hatred against Edom in other related texts. As surveyed above, Doeg is not the only example of the 'Edomophobia' in the biblical texts. Instead, there are other narratives which describe the hatred against Edom, even though they do not include Doeg. Being located in the DH, however, Doeg reinstates the exilic or post-exilic hatred against Edomites. The appearance of Doeg at the temple can be connected to a covert enmity of the Golah community against any assumed presence of Edomite cultic or liturgical offices in Jerusalem (Tebes 2011:252). Furthermore, his slaughter of the priests of the LORD at the command of Saul can be considered as a clear example showing the abominable character of the Edomites. Because of Doeg, Saul and his other servants did not have to kill the priests of the LORD with their hands. Any critical blame of the massacre cannot be found in any Israelite but in the Edomite servant. As a result, Doeg in 1 Samuel 21 and 22 was used as a device of propaganda to justify 'Edomophobia', the enmity of the exilic or post-exilic community towards the Edomites and the incompatibility between those two ethnic groups.

\section{Acknowledgements Competing interests}

The author declares that he has no financial or personal relationships which may have inappropriately influenced him in writing this article.

\section{References}

Alter, R., 1981, The art of biblical narrative, Basic Books, New York.

Alter, R., 1999, The David story: A translation with commentary of 1 and 2 Samuel, W.W. Norton, New York.

Aster, S.Z., 2003, 'What was Doeg the Edomite's title? Textual emendation versus a comparative approach to 1 Samuel 21:8', Journal of Biblical Literature 122, 353361. https://doi.org/10.2307/3268449

Bartlett, J.R., 1989, Edom and the Edomites, Journal for the Study of the Old Testament Supplement Series, JSOT Press, Sheffield.

Bartlett, J.R., 1992, 'Edom (Edom in History)', in D.N. Freedman, G.A. Herion, D.F. Graf, J.D. Pleins, A.B. Beck (eds.), The anchor Bible Dictionary, vol. 2, pp. 287-294, D-G. Doubleday, New York.

Bodner, K., 2008, 1 Samuel: A narrative commentary, Sheffield Phoenix Press, Sheffield.

Brueggemann, W., 1990, 'First and Second Samuel', Interpretation, A Bible commentary for teaching and preaching, 1st edn., Westminster/John Knox Press, Louisville, KY.

Campbell, A.F. \& O'Brien, M.A., 2000, Unfolding the Deuteronomistic History: Origins, upgrades, present text, Fortress Press, Minneapolis, MN.

Fokkelman, J.P., 1986, Narrative art and poetry in the Books of Samuel: A full interpretation based on stylistic and structural analyses, Van Gorcum, Dover, $\mathrm{NH}$.

Hertzberg, H.W., 1964, I \& II Samuel, A commentary, Westminster Press, Philadelphia,

Jobling, D., 1998, 1 Samuel, Berit Olam, Liturgical Press, Collegeville, MN.

Kalimi, I., 'Was the chronicler a historian?', in M.P. Graham, K.G. Hoglund \& S.L. McKenzie (eds.), The chronicler as historian, pp. 73-89, Sheffield Academic Press, Sheffield.

Klein, R.W., 1983, 1 Samuel, Word Books, Waco, TX.

Lemaire, A., 2006, 'Nabonidus in Arabia and Judah in the Neo-Babylonian Period', in O. Lipschits \& J. Blenkinsopp (eds.), Judah and the Judeans in the Neo-Babylonian Period, pp. 285-298, Eisenbrauns, Winona Lake, IN

Lemaire, A., 2010, 'Edom and the Edomites', in A. Lemaire, B. Halpern \& M.J. Adams (eds.), Books of kings: Sources, composition, historiography, and reception, pp. 225-243, Brill, Leiden.

Lozovyy, J., 2009, Saul, Doeg, Nabal, and the 'Son of Jesse': Readings in 1 Samuel 1625, T \& T Clark International, London.

McCarter, P.K., 1980, I Samuel: A new translation, 1st edn., Doubleday, Garden City.

Peterson, B.N., 2014, The authors of the deuteronomistic history: Locating a tradition in ancient Israel, Fortress, Minneapolis, MN.

Pritchard, J.B., 1969, Ancient near Eastern texts: Relating to the Old Testament, 3rd edn., Princeton University Press, Princeton, NJ.

Römer, T., 2007, The so-called deuteronomistic history: A sociological, historical and literary introduction, T \& T Clark, London.

Sasson, J.M., 2004, 'Doeg's Job', Scriptura 87, 317-322. https://doi.org/10.7833/87-0-

Tate, M.E., 1990, Psalms 51-100, Word Books, Dallas, TX.

Tebes, J.M., 2011, 'The Edomite involvement in the destruction of the first temple: A case of Stab-in-the-Back tradition?', Journal for the Study of the Old Testament 36, 219-255. https://doi.org/10.1177/0309089211423731

Tsumura, D.T., 2007, The first book of Samuel, new international commentary on the Old Testament, William B. Eerdmans, Grand Rapids, MI. 